\title{
Synthesis and Evaluation of New 2-Iminothiazolidin-4-one and Thia- zolidin-2,4-dione Derivatives as Antimicrobial and Anti-inflammatory Agents
}

\author{
Waleed A. Bayoumi ${ }^{1, *}$, Shaymaa H. Abdel-Rhman ${ }^{2}$ and Mohamed E. Shaker ${ }^{3}$ \\ ${ }^{I}$ Department of Pharmaceutical Organic Chemistry, Faculty of Pharmacy, University of Mansoura, Mansoura 35516, \\ Egypt; ${ }^{2}$ Department of Microbiology, Faculty of Pharmacy, University of Mansoura, Mansoura 35516, Egypt; \\ ${ }^{3}$ Department of Pharmacology and Toxicology, Faculty of Pharmacy, University of Mansoura, Mansoura 35516, Egypt
}

\begin{abstract}
A new series of 2-iminothiazolidin-4-ones and thiazolidin-2,4-diones were designed and synthesized. The target compounds were evaluated for antimicrobial and anti-inflammatory activities, aiming to find a candidate carrying dual activities. The antibacterial activity was determined by cup-diffusion technique and NCCLS broth dilution method. The MICs were determined using 96-well microtitre plates, while the anti-inflammatory activity was determined using carrageenan-induced rat paw edema model. The results revealed that target compounds showed no antifungal activity towards tested Fungi, whereas the antibacterial activity was mainly on Gram-positive bacteria. The anti-inflammatory activity was observed in compounds belonging to the thiazolidin-2,4-dione series. The structures of the newly synthesized compounds were confirmed by physical and spectral data.
\end{abstract}

Keywords: 2-iminothiazolidin-4-ones, anti-inflammatory, antimicrobial, synthesis, thiazolidin-2,4-diones.

\section{INTRODUCTION}

The search for new anti-inflammatory agents devoid of potential undesirable side effects and new antimicrobial agents capable of overcoming the problem of increasing microbial resistance continues to be an active research area in pharmaceutical chemistry. Of the most interesting heterocyclic scaffolds available for modulation of biological activity are: thiazolidinone and thiazolidindione. Their different biological activities were reported $[1,2]$. Among the most important biological and pharmacological activities of both heterocyclic pharmacophoric moieties are: antihyperglycemic [3, 4], antibacterial [5-9], antifungal [10, 11], antiinflammatory [12-17], cyclooxygenase and lipoxygenase inhibitors [18, 19], anticonvulsants [20,21], antitumor [22], antioxidant [23] and several other activities [1,2].

Those reported variable and numerous pharmacological activities encouraged us to design and synthesize lead molecules of thiazolidinone and thiazolidindione pharmacophores carrying potential antimicrobial and anti-inflammatory activities. Thus, the primary aim of this research is to find newer generations possessing more potent and safe therapeutic profile.

Structure diversity was accomplished by introducing different (un)substituted arylidene functionality at the 5position of the two core skeletones 2-iminothiazol-4-ones (4a-4d) and thiazolidin-2,4-diones (7a-7d). This arylidene side arm was designed to act as potential bioactive moiety

*Address correspondence to this author at the Department of Pharmaceutical Organic Chemistry, Faculty of Pharmacy, University of Mansoura, Mansoura 35516, Egypt; Tel: +20 1115633 722;

Fax: +20 5022 4749; E-mail: waleedbayoumi@mans.edu.eg imparting a modification in certain physicochemical properties e.g., lipophilicity and steric effect [24-26].

In addition, a benzenesulfonamide moiety was introduced at the 3-position of both skeletons; directly in $\mathbf{4 a - 4 d}$ and via an acetamide linker in $\mathbf{7 a - 7 d}$. The benzenesulfonamide moiety was reported to be important for potentiation of both antimicrobial and anti-inflammatory activities [27-30]. Target skeletons and their structural modifications are illustrated in Fig. (1).

\section{EXPERIMENTAL}

\section{Chemistry}

Melting points were determined in a capillary tube using Electrothermal C14500 apparatus and are uncorrected. NMR spectra were recorded on a Bruker AC spectrometer (400 $\mathrm{MHz}-{ }^{1} \mathrm{H}$ and $100.0 \mathrm{MHz}-{ }^{13} \mathrm{C}$ ) in DMSO- $d_{6}$. Chemical shifts in ppm are given as $\delta$ values against tetramethylsilane as the internal standard. MS analyses were performed on Thermo Fisher Scientific Trace DSQ II, Mass spectrometer at Central Research Lab, Faculty of Pharmacy, Mansoura University. Elemental Microanalyses were performed by the microanalytical centre, Cairo University. Reactions were monitored by TLC performed on silica gel plates (Merck 60 $\left.F_{245}\right)$ and using ethyl acetate: petroleum ether (1:1) as eluent, the spots were visualized by U.V $(366,245 \mathrm{~nm})$. Compounds 5 [31], 6a-6d [32] were prepared according to the reported procedures.

\section{2-Chloro- $N$-(4-sulfamoylphenyl)acetamide (1)}

Chloroacetyl chloride $(8 \mathrm{~mL})$ was added slowly over a period of $30 \mathrm{~min}$ to a solution of sulfanilamide (17.2 g, 100 $\mathrm{mmol})$ in DMF $(50 \mathrm{~mL})$. Stirring was continued for $1 \mathrm{~h}$. 


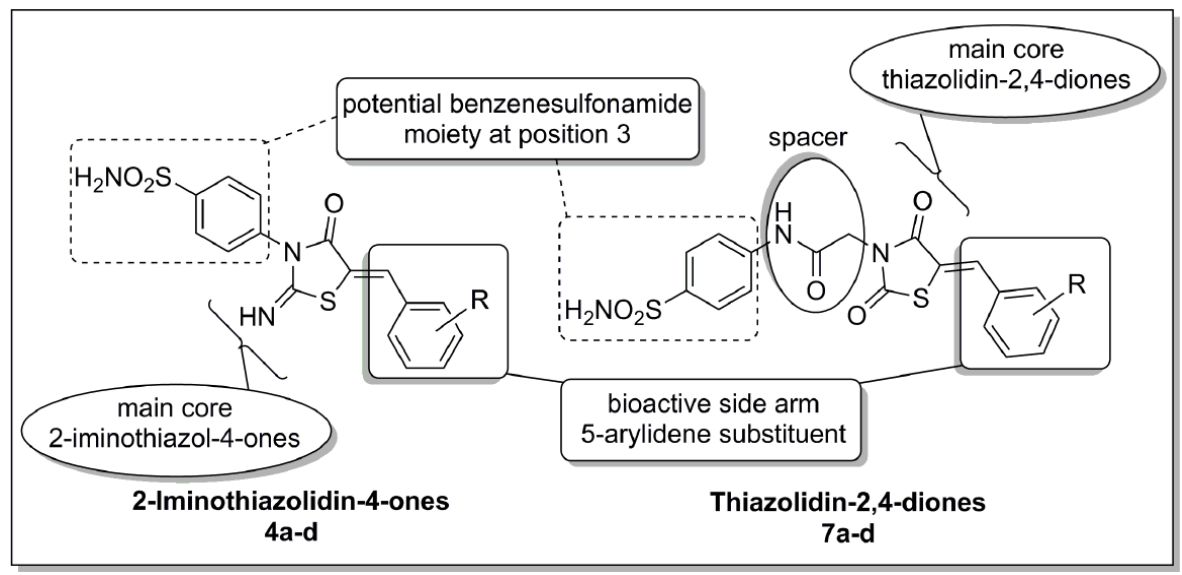

Fig. (1). Design of target 2-iminothiazol-4-ones (4a-4d) and thiazolidin-2,4-diones (7a-7d).

The reaction mixture was quenched with cold water (150 $\mathrm{mL})$. The formed precipitate was collected by filtration, washed with cold water, dried and recrystallized from methanol to afford pure product. Colorless crystals, yield $85 \%, \operatorname{mp} 218-220^{\circ} \mathrm{C}[33]$.

\section{4-(2-Imino-4-oxothiazolidin-3-yl)benzenesulfonamide (3)}

A mixture of $1(2.48 \mathrm{~g}, 10 \mathrm{mmol})$ and $\mathrm{NH}_{4} \mathrm{SCN}(1.52 \mathrm{~g}$, $20 \mathrm{mmol})$ in acetone $(25 \mathrm{~mL})$ was refluxed for $2 \mathrm{~h}$. The formed precipitate was filtered and dried. The dried solid product was then heated with DMF $(20 \mathrm{~mL})$ at $120-130{ }^{\circ} \mathrm{C}$ for $1 \mathrm{~h}$. the reaction mixture was cooled to $\mathrm{rt}$ and poured over crushed ice to afford white crystalline product, which was filtered, dried and recrystallized from ethanol to afford pure product. White crystals, yield $70 \%$, mp $258-260{ }^{\circ} \mathrm{C}$ (reported mp $258^{\circ} \mathrm{C}$ ) [34].

Synthesis of (Z)-4-(2-Imino-5-((un)substituted benzylidene)-4-oxothiazolidin-3-yl)benzenesulfonamides (4a4d)

\section{General Procedure:}

Method 1; a mixture of $3(2.71 \mathrm{~g}, 10 \mathrm{mmol})$, the appropriate aromatic aldehyde $(10 \mathrm{mmol})$ and catalytic amount of pyridine in xylene $(25 \mathrm{~mL})$ was heated at reflux for $6 \mathrm{~h}$. After cooling to $\mathrm{rt}$, the formed precipitate was filtered, dried and recrystallized from isopropyl alcohol to afford pure products. Method 2; a mixture of $3(2.71 \mathrm{~g}, 10 \mathrm{mmol})$, the appropriate aromatic aldehyde $(10 \mathrm{mmol})$ and catalytic amount of sodium acetate in glacial acetic acid $(25 \mathrm{~mL})$ was heated at reflux for $5 \mathrm{~h}$. After cooling to $\mathrm{rt}$, the formed precipitate was filtered, washed thoroughly with cold water, dried and recrystallized from isopropyl alcohol to afford pure products.

\section{(Z)-4-(5-Benzylidene-2-imino-4-oxothiazolidin-3- yl)benzenesulfonamide (4a)}

Yellowish white crystals, mp 243-45 ${ }^{\circ} \mathrm{C}$, yield $60 \%$ (method 1), 65\% (method 2). Analysis for $\mathrm{C}_{16} \mathrm{H}_{13} \mathrm{~N}_{3} \mathrm{O}_{3} \mathrm{~S}_{2}$ (359.42), Calcd.: C, 53.47; H, 3.65; N, 11.69; Found: C, $53.52 ; \mathrm{H}, 3.59 ; \mathrm{N}, 11.74 .{ }^{1} \mathrm{H}$ NMR (DMSO- $\left.d_{6}\right): \delta 9.96(\mathrm{~s}$, $1 \mathrm{H}, \mathrm{NH}, \mathrm{D}_{2} \mathrm{O}$ exchangeable), $7.96(\mathrm{~d}, 2 \mathrm{H}, J=8.8 \mathrm{~Hz}, \mathrm{H}-3$ and H-5), 7.83 (s, 1H, C=CH), 7.74-7.57 (m, 3H, H-3', H-4' and H-5'), 7.52 (d, 2H, J=6.4 Hz, H-2 and H-6), 7.33 (s, 2H,
$\mathrm{SO}_{2} \mathrm{NH}_{2}, \mathrm{D}_{2} \mathrm{O}$ exchangeable), $7.22(\mathrm{~d}, 2 \mathrm{H}, J=7.7 \mathrm{~Hz}, \mathrm{H}-2$ ' and H-6'). ${ }^{13} \mathrm{C}$ NMR (DMSO- $d_{6}$ ): $\delta$ 171.9, 165.7, 141.0, $140.2,132.8,132.3,130.1,129.4,128.8,127.3,126.8,120.4$. MS $m / z$ (\% Rel. Int.): $359\left(24.56, \mathrm{M}^{+}\right)$.

\section{(Z)-4-(2-Imino-5-(4-methoxybenzylidene)-4-oxothiazolidin- 3-yl)benzenesulfonamide (4b)}

Yellow crystals, mp 256-58 ${ }^{\circ} \mathrm{C}$, yield 75\% (method 1 ), $75 \%$ (method 2). Analysis for $\mathrm{C}_{17} \mathrm{H}_{15} \mathrm{~N}_{3} \mathrm{O}_{4} \mathrm{~S}_{2}$ (389.45), Calcd.: C, 52.43; H, 3.88; N, 10.79; Found: C, $52.50 ; \mathrm{H}$, 3.72; N, 10.71. ${ }^{1} \mathrm{H}$ NMR (DMSO- $\left.d_{6}\right): \delta 9.88(\mathrm{~s}, 1 \mathrm{H}, \mathrm{NH}$, $\mathrm{D}_{2} \mathrm{O}$ exchangeable), $7.95(\mathrm{~d}, 2 \mathrm{H}, J=8.4 \mathrm{~Hz}, \mathrm{H}-3$ and $\mathrm{H}-5)$, $7.83(\mathrm{~s}, 1 \mathrm{H}, \mathrm{C}=\mathrm{CH}), 7.62$ (d, 1H, J=8.4 Hz, H-3'), 7.58 (d, $\left.1 \mathrm{H}, J=8.4 \mathrm{~Hz}, \mathrm{H}-5^{\prime}\right), 7.51$ (d, 2H, $J=7.6 \mathrm{~Hz}, \mathrm{H}-2$ and H-6), 7.33 (s, 2H, $\mathrm{SO}_{2} \mathrm{NH}_{2}, \mathrm{D}_{2} \mathrm{O}$ exchangeable), 7.14 (d, 2H, $J=8.8$ $\mathrm{Hz}, \mathrm{H}-2$ ' and H-6'), 3.93 (s, 3H, $\left.\mathrm{OCH}_{3}\right) .{ }^{13} \mathrm{C}$ NMR (DMSO$\left.d_{6}\right): \delta 170.3,167.5,161.6,141.4,141.3,131.9,130.8,129.6$, 127.9, 125.8, 120.9, 114.3, 56.0. MS m/z (\% Rel. Int.): 389 $\left(7.50, \mathrm{M}^{+}\right)$.

\section{(Z)-4-(5-(3,4-Dimethoxybenzylidene)-2-imino-4- oxothiazolidin-3-yl)benzenesulfonamide (4c)}

Yellow crystals, mp 237-39 ${ }^{\circ} \mathrm{C}$, yield $71 \%$ (method 1 ), $68 \%$ (method 2). Analysis for $\mathrm{C}_{18} \mathrm{H}_{17} \mathrm{~N}_{3} \mathrm{O}_{5} \mathrm{~S}_{2}$ (419.47), Calcd.: C, 51.54; H, 4.08; N, 10.02; Found: C, 51.60 ; H, 3.99; N, 10.08. ${ }^{1} \mathrm{H}$ NMR (DMSO- $\left.d_{6}\right): \delta 9.88(\mathrm{~s}, 1 \mathrm{H}, \mathrm{NH}$, $\mathrm{D}_{2} \mathrm{O}$ exchangeable), 7.95 (d, 2H, $J=7.6 \mathrm{~Hz}, \mathrm{H}-3$ and $\left.\mathrm{H}-5\right)$, 7.83 (s, 1H, C=CH), 7.69 (d, 1H, J=10.8 Hz, H-6'), 7.62 (d, $1 \mathrm{H}, J=8 \mathrm{~Hz}, \mathrm{H}-5$ '), 7.52 (d, 2H, $J=7.2 \mathrm{~Hz}, \mathrm{H}-2$ and H-6), 7.33 (s, 2H, $\mathrm{SO}_{2} \mathrm{NH}_{2}, \mathrm{D}_{2} \mathrm{O}$ exchangeable), 7.25 (s, 1H, H-2'), $3.95\left(\mathrm{~s}, 6 \mathrm{H}, 2 \mathrm{OCH}_{3}\right) .{ }^{13} \mathrm{C}$ NMR (DMSO- $\left.d_{6}\right): \delta 170.8,163.9$, $152.1,149.1,141.9,140.8,130.3,130.2,128.3,126.5,124.1$, 120.6, 113.4, 112.2, 56.8. MS m/z (\% Rel. Int.): 419 (4.39, $\mathrm{M}^{+}$).

\section{(Z)-4-(5-(2-Chloro-5-nitrobenzylidene)-2-imino-4- oxothiazolidin-3-yl)benzenesulfonamide (4d)}

Orange crystals, mp 191-193 ${ }^{\circ} \mathrm{C}$, yield $63 \%(\operatorname{method} 1)$, $65 \%$ (method 2). Analysis for $\mathrm{C}_{16} \mathrm{H}_{11} \mathrm{ClN}_{4} \mathrm{O}_{5} \mathrm{~S}_{2}$ (438.87), Calcd.: C, 43.79; H, 2.53; N, 12.77; Found: C, 43.65; H, 2.62; N, 12.66. ${ }^{1} \mathrm{H}$ NMR (DMSO- $\left.d_{6}\right): \delta 10.27(\mathrm{~s}, 1 \mathrm{H}, \mathrm{NH}$, $\mathrm{D}_{2} \mathrm{O}$ exchangeable), 8.38 ( $\mathrm{s}, 1 \mathrm{H}, \mathrm{H}-6$ '), 8.30 (d, $2 \mathrm{H}, J=8.4$ $\mathrm{Hz}, \mathrm{H}-3$ and $\mathrm{H}-5), 8.18(\mathrm{~s}, 1 \mathrm{H}, \mathrm{C}=\mathrm{CH}), 7.98(\mathrm{~d}, 1 \mathrm{H}, J=8.4$ Hz, H-4'), 7.66 (d, 2H, J=8.4 Hz, H-2 and H-6), 7.53 (s, 2H, 
$\mathrm{SO}_{2} \mathrm{NH}_{2}, \mathrm{D}_{2} \mathrm{O}$ exchangeable), $7.40(\mathrm{~d}, 1 \mathrm{H}, J=7.6 \mathrm{~Hz}, \mathrm{H}-3$ ') ${ }^{13} \mathrm{C}$ NMR (DMSO- $d_{6}$ ): $\delta 172.7,164.6,145.4,142.1,140.9$, $140.2,131.5,130.8,129.9,128.6,126.4,125.2,123.4,120.7$. MS $m / z$ (\% Rel. Int.): $438\left(6.50, \mathrm{M}^{+}\right)$.

Synthesis of (Z)-2-(5-(un)substituted benzylidene-2,4dioxothiazolidin-3-yl)-N-(4-sulfamoylphenyl)acetamides (7a-7d)

General procedure: a mixture of $1(2.49 \mathrm{~g}, 10 \mathrm{mmol})$, the appropriate 6a-6d $(10 \mathrm{mmol})$ and $\mathrm{K}_{2} \mathrm{CO}_{3}(2 \mathrm{~g})$ in DMF (25 $\mathrm{mL}$ ) was stirred overnight at rt. Quenching with ice-cold water $(50 \mathrm{~mL})$ precipitated the product, which was filtered, dried and recrystallized from DMF:water (1:1) mixture to afford pure products.

\section{(Z)-2-(5-Benzylidene-2,4-dioxothiazolidin-3-yl)-N-(4- sulfamoylphenyl)acetamide (7a)}

Yellow crystals, mp $250-252^{\circ} \mathrm{C}$, yield $60 \%$. Analysis for $\mathrm{C}_{18} \mathrm{H}_{15} \mathrm{~N}_{3} \mathrm{O}_{5} \mathrm{~S}_{2}$ (417.46), Calcd.: C, 51.79; H, 3.62; N, 10.07; Found: C, $51.68 ; \mathrm{H}, 3.70 ; \mathrm{N}, 10.11 .{ }^{1} \mathrm{H}$ NMR (DMSO- $\left.d_{6}\right): \delta$ $10.73\left(\mathrm{~s}, 1 \mathrm{H}, \mathrm{NH}, \mathrm{D}_{2} \mathrm{O}\right.$ exchangeable), $8.02(\mathrm{~s}, 1 \mathrm{H}, \mathrm{C}=\mathrm{CH})$, $7.81(\mathrm{~d}, 2 \mathrm{H}, J=8 \mathrm{~Hz}, \mathrm{H}-3$ and $\mathrm{H}-5), 7.75(\mathrm{~d}, 2 \mathrm{H}, J=7.6 \mathrm{~Hz}$, H-2 and H-6), 7.60 (d, 2H, $J=7.6 \mathrm{~Hz}, \mathrm{H}-2^{\prime}$ and H-6'), 7.587.53 (m, 3H, H-3', H-4' and H-5'), 7.31 (s, 2H, $\mathrm{SO}_{2} \mathrm{NH}_{2}$, $\mathrm{D}_{2} \mathrm{O}$ exchangeable), $4.59\left(\mathrm{~s}, 2 \mathrm{H}, \mathrm{CH}_{2}\right) .{ }^{13} \mathrm{C}$ NMR (DMSO$\left.d_{6}\right): \delta 180.2,167.1,165.7,142.7,139.3,132.8,130.6,130.1$, 129.4, 128.8, 127.9, 120.4, 114.6. 45.9. MS $m / z$ (\% Rel. Int.): $417\left(26.11, \mathrm{M}^{+}\right)$.

\section{(Z)-2-(5-(4-Methoxybenzylidene)-2,4-dioxothiazolidin-3- yl)-N-(4-sulfamoylphenyl)acetamide (7b)}

Yellow crystals, mp $224-226^{\circ} \mathrm{C}$, yield $68 \%$. Analysis for $\mathrm{C}_{19} \mathrm{H}_{17} \mathrm{~N}_{3} \mathrm{O}_{6} \mathrm{~S}_{2}$ (447.48), Calcd.: C, 51.00; H, 3.83; N, 9.39; Found: C, 51.04; H, 3.78; N, 9.42. ${ }^{1} \mathrm{H}$ NMR (DMSO- $\left.d_{6}\right): \delta$ $10.76\left(\mathrm{~s}, 1 \mathrm{H}, \mathrm{NH}, \mathrm{D}_{2} \mathrm{O}\right.$ exchangeable), $7.97(\mathrm{~s}, 1 \mathrm{H}, \mathrm{C}=\mathrm{CH})$, $7.80(\mathrm{~d}, 2 \mathrm{H}, J=8 \mathrm{~Hz}, \mathrm{H}-3$ and $\mathrm{H}-5), 7.73(\mathrm{~d}, 2 \mathrm{H}, J=8.4 \mathrm{~Hz}$, H-2 and H-6), 7.65 (d, 2H, J=8 Hz, H-2' and H-6'), 7.29 (s, $2 \mathrm{H}, \mathrm{SO}_{2} \mathrm{NH}_{2}, \mathrm{D}_{2} \mathrm{O}$ exchangeable), $7.14(\mathrm{~d}, 2 \mathrm{H}, \mathrm{J}=8.4 \mathrm{~Hz}, \mathrm{H}-$ $3^{\prime}$ and $\mathrm{H}-5$ '), $4.59\left(\mathrm{~s}, 2 \mathrm{H}, \mathrm{CH}_{2}\right), 3.86\left(\mathrm{~s}, 3 \mathrm{H}, \mathrm{OCH}_{3}\right) .{ }^{13} \mathrm{C}$ NMR (DMSO- $\left.d_{6}\right): \delta 180.2,167.1,165.7,161.6,142.7$, 139.3, 130.8, 130.6, 127.9, 125.9, 120.4, 114.6, 114.3, 56.0, 45.9. MS $m / z$ (\% Rel. Int.): 447 (22.60, $\mathrm{M}^{+}$).

\section{(Z)-2-(5-(3,4-Dimethoxybenzylidene)-2,4-dioxothiazolidin- 3-yl)-N-(4-sulfamoylphenyl)acetamide (7c)}

Pale yellow crystals, mp 205-207 ${ }^{\circ} \mathrm{C}$, yield $65 \%$. Analysis for $\mathrm{C}_{20} \mathrm{H}_{19} \mathrm{~N}_{3} \mathrm{O}_{7} \mathrm{~S}_{2}$ (477.51), Calcd.: C, 50.31; H, 4.01; N, 8.80; Found: C, 50.38; H, 4.95; N, 8.87. ' H NMR (DMSO$\left.d_{6}\right): \delta 10.57\left(\mathrm{~s}, 1 \mathrm{H}, \mathrm{NH}, \mathrm{D}_{2} \mathrm{O}\right.$ exchangeable $), 7.94(\mathrm{~s}, 1 \mathrm{H}$, $\mathrm{C}=\mathrm{CH}), 7.82(\mathrm{~d}, 2 \mathrm{H}, J=7.6 \mathrm{~Hz}, \mathrm{H}-3$ and $\mathrm{H}-5), 7.72(\mathrm{~d}, 2 \mathrm{H}$, $J=8.8 \mathrm{~Hz}, \mathrm{H}-2$ and H-6), 7.27 (d, 1H, $J=8 \mathrm{~Hz}, \mathrm{H}-6$ '), 7.16 (s, $1 \mathrm{H}, \mathrm{H}-2$ ') 7.17 (d, $1 \mathrm{H}, J=8 \mathrm{~Hz}, \mathrm{H}-5$ '), 7.04 (s, 2H, $\mathrm{SO}_{2} \mathrm{NH}_{2}$, $\mathrm{D}_{2} \mathrm{O}$ exchangeable), $4.58\left(\mathrm{~s}, 2 \mathrm{H}, \mathrm{CH}_{2}\right), 3.87\left(\mathrm{~s}, 6 \mathrm{H}, 2 \mathrm{OCH}_{3}\right)$. ${ }^{13} \mathrm{C}$ NMR (DMSO- $d_{6}$ ): $\delta 180.2,167.1,165.7,152.1,149.1$, $142.7,139.3,129.4,127.9,126.5,124.1,120.4,113.9,113.4$, 112.5, 56.8, 45.9. MS m/z (\% Rel. Int.): 477 (21.00, $\left.\mathrm{M}^{+}\right)$.

\section{(Z)-2-(5-(2-Chloro-5-nitrobenzylidene)-2,4-dioxothiazo- lidin-3-yl)-N-(4-sulfamoylphenyl)acetamide (7d)}

Pale yellow crystals, mp 212-214 ${ }^{\circ} \mathrm{C}$, yield 55\%. Analysis for $\mathrm{C}_{18} \mathrm{H}_{13} \mathrm{ClN}_{4} \mathrm{O}_{7} \mathrm{~S}_{2}$ (496.90), Calcd.: C, 43.51; H, 2.64; $\mathrm{N}, 11.28$; Found: C, 43.58; H, 2.70; N, 11.19. ${ }^{1} \mathrm{H}$ NMR
(DMSO- $\left.d_{6}\right): \delta 10.59\left(\mathrm{~s}, 1 \mathrm{H}, \mathrm{NH}, \mathrm{D}_{2} \mathrm{O}\right.$ exchangeable), 8.20 (s, 1H, H-6'), 8.01 (d, 1H, J=7.6 Hz, H-6'), 7.90 (s, 1H, $\mathrm{C}=\mathrm{CH}), 7.79(\mathrm{~d}, 2 \mathrm{H}, J=7.6 \mathrm{~Hz}, \mathrm{H}-3$ and $\mathrm{H}-5), 7.69(\mathrm{~d}, 2 \mathrm{H}$, $J=8.8 \mathrm{~Hz}, \mathrm{H}-2$ and H-6), 7.51 (d, 1H, $J=7.6 \mathrm{~Hz}, \mathrm{H}-3$ '), 7.04 (s, $2 \mathrm{H}, \mathrm{SO}_{2} \mathrm{NH}_{2}, \mathrm{D}_{2} \mathrm{O}$ exchangeable), $4.55\left(\mathrm{~s}, 2 \mathrm{H}, \mathrm{CH}_{2}\right) .{ }^{13} \mathrm{C}$ NMR (DMSO- $\left.d_{6}\right)$ : $\delta$ 180.2, 167.1, 165.7, 145.4, 142.7, $140.3,139.3,131.5,130.8,127.9,125.9,125.7,120.6,120.4$, 117.1, 45.9. MS $m / z$ (\% Rel. Int.): $496\left(13.44, \mathrm{M}^{+}\right)$.

\section{Antimicrobial Screening}

The antimicrobial activity of the synthesized compounds has been studied using the cup-diffusion technique [35]. The tested compounds were screened against Staphylococcus aureus and Bacillus subtilis as examples for Gram-positive bacteria, Escherichia coli and Pseudomonas aeruginosa as examples for Gram-negative bacteria and Candida albicans and Candida tropicalis as example for fungi.

In this technique pores were made using a sterile cork borer in the solidified agar medium and an aliquot of 0.05 $\mathrm{mL}$ of $1000 \mu \mathrm{g} / \mathrm{mL}$ of the tested substance is placed in each pore in the nutrient agar medium on which a culture of the tested bacteria has been spread to produce uniform growth. After $24 \mathrm{~h}$ incubation at $37^{\circ} \mathrm{C}$, the diameter of inhibition zone is measured in $\mathrm{mm}$.

Compounds that exhibited good anti-Gram-positive bacteria were assayed in vitro against Staphylococcus aureus and Bacillus subtilis. The organisms were obtained from the Microbiology Laboratory, Department of Microbiology, Faculty of Pharmacy, University of Mansoura. The antibacterial assay was carried out using NCCLS broth dilution method [36, 37]. The minimum inhibitory concentrations (MICs) were determined using 96-well microtitre plates. The bacterial suspension was adjusted with sterile saline to a concentration of $1.0 \times 10^{5}$ c.f.u. $/ \mathrm{mL}$. Compounds to be investigated were dissolved in DMSO. The microplates were incubated for $24 \mathrm{~h}$ at $37^{\circ} \mathrm{C}$. In order to ensure that the solvent had no effect on bacterial growth, a control test was performed containing broth supplemented with only DMSO. The lowest concentrations without visible growth were defined as concentrations that completely inhibited bacterial growth (MICs).

Ampicillin was used as a reference standard to compare the antibacterial activity. All experiments were performed in duplicate and repeated three times. The MIC values were expressed in $\mu \mathrm{g} / \mathrm{mL}$ and the results of the most active compounds are shown in Table $\mathbf{1}$.

Table 1. Minimum inhibitory concentrations (MICs) in $(\mu \mathrm{g} / \mathrm{mL})$ of the most active compounds.

\begin{tabular}{|c|c|c|}
\hline \multirow{2}{*}{ Entry } & \multicolumn{2}{|c|}{ MICs $(\boldsymbol{\mu g} / \mathbf{m L})$} \\
\cline { 2 - 3 } & Staphylococcus aureus & Bacillus. subtilis \\
\hline \hline Ampicillin & 62.5 & 62.5 \\
\hline 4a & $>1000$ & 250 \\
\hline $7 \mathbf{a}$ & 1000 & 62.5 \\
\hline 7d & 500 & 250 \\
\hline
\end{tabular}




\section{Anti-Inflammatory Screening}

\section{Carrageenan-Induced Rat Paw Edema Assay}

The anti-inflammatory activity of the test compounds was carried out using carrageenan-induced rat paw edema model [38] by employing carrageenan solution as the phlogistic agent. Male Wistar albino rats weighing 150-180 g were kept in the animal house under standard conditions of light and temperature with free access to food and water. After overnight fasting, the animals were randomly divided into groups each consisting of six rats. The first group served as a control and received only the vehicle $(1 \mathrm{~mL} / \mathrm{kg}$, i.p., $10 \% \mathrm{v} / \mathrm{v}$ of DMSO in normal saline). Another group received the standard drug Diclofenac K (10 mg/kg, i.p., $1 \%$ $\mathrm{w} / \mathrm{v}$ the vehicle). Other groups of rats were administered the test compounds in equal doses $(100 \mathrm{mg} / \mathrm{kg}$, i.p.; w/v in $10 \%$ $\mathrm{w} / \mathrm{v}$ the vehicle). Thirty minutes after administration of the standard drug and test compounds, $0.1 \mathrm{~mL}$ of $1 \% \mathrm{w} / \mathrm{v}$ of $\lambda$ carrageenan (Type IV, Sigma-Aldrich, USA) suspension in sterile normal saline was injected into the subplanter region of the right hind paw of each rat. After $4 \mathrm{hr}$, the paw thickness was measured with electronic digital calipers, and the difference in the paw thickness of between the injected and the control was recorded for each rat. The edema was expressed as the percentage of increase in the paw thickness, and the percentage of inhibition of edema for each group.

\section{Statistical Analysis}

Data obtained from animal experiments were expressed as mean \pm standard error (S.E.M.). The statistical significance of difference between groups were determined by means of analysis of variance (ANOVA) followed by Dunnet's test. The results of the anti-inflammatory studies have been presented in Table 2 .

Table 2. Results of anti-inflammatory Screening.

\begin{tabular}{|c|c|c|}
\hline $\begin{array}{c}\text { Entry } \\
(\mathbf{d o s e})\end{array}$ & $\begin{array}{c}\text { \% of increase } \\
\text { in paw thickness }\end{array}$ & $\begin{array}{c}\text { \% of inhibition } \\
\text { of edema }\end{array}$ \\
\hline \hline $\begin{array}{c}\text { Diclofenac K } \\
(10 \mathrm{mg} / \mathrm{kg})\end{array}$ & $32.48 \pm 3.24^{* *}$ & 72.29 \\
\hline $\begin{array}{c}\mathbf{7 b} \\
(100 \mathrm{mg} / \mathrm{kg})\end{array}$ & $48.75 \pm 7.11^{* *}$ & 58.40 \\
\hline $\begin{array}{c}\mathbf{7} \mathbf{c} \\
(100 \mathrm{mg} / \mathrm{kg})\end{array}$ & $61.86 \pm 2.2^{* *}$ & 47.22 \\
\hline $\begin{array}{c}\mathbf{7 a} \\
(100 \mathrm{mg} / \mathrm{kg})\end{array}$ & $62.3 \pm 4.77^{* *}$ & 46.84 \\
\hline $\begin{array}{c}\mathbf{7 d} \\
(100 \mathrm{mg} / \mathrm{kg})\end{array}$ & $64.66 \pm 5.01^{* *}$ & 44.83 \\
\hline $\begin{array}{c}\mathbf{4 a} \\
(100 \mathrm{mg} / \mathrm{kg})\end{array}$ & $78.53 \pm 3.78^{* *}$ & 32.99 \\
\hline $\begin{array}{c}\mathbf{4 b} \\
(100 \mathrm{mg} / \mathrm{kg})\end{array}$ & $81.66 \pm 3.59^{* *}$ & 30.32 \\
\hline $\begin{array}{c}\mathbf{4 c} \\
(100 \mathrm{mg} / \mathrm{kg})\end{array}$ & $83.89 \pm 5.4^{* *}$ & 28.42 \\
\hline $\begin{array}{c}\mathbf{4 d} \\
(100 \mathrm{mg} / \mathrm{kg})\end{array}$ & $87.94 \pm 7.75^{* *}$ & 24.97 \\
\hline Control $(\mathrm{Carrageenan}$ only $)$ & $117.2 \pm 5.64$ & - \\
\hline
\end{tabular}

Values are expressed as mean \pm SEM, $\mathrm{n}=6$ in each group, ${ }^{* *} P<0.01$ compared with the control.

\section{RESULTS AND DISCUSSION}

\section{Chemistry}

The synthetic methods used for preparation of target compounds are depicted in Schemes 1-5. Compound 1, the precursor of the starting compound was prepared by chloroacetylation of sulfanilamide using chloroacetyl chloride in DMF as a solvent. The starting compound, 3 was prepared through a two-steps reaction. The first step is a nucleophilic substitution of $\mathrm{NH}_{4} \mathrm{SCN}$ with 1 using acetone as a solvent to afford the intermediate $N$-(4-sulfamoylphenyl)-2thiocyanatoacetamide $\mathbf{2}$, followed by thermal cyclization using DMF as a polar aprotic solvent. The postulated mechanism for heterocyclic cyclization is illustrated (Scheme 1). The synthesis of compound 3 was reported earlier to proceed in a one-step reaction using ethanol or acetone as solvents, but it was observed that the purity of the product was better when using the two-steps synthesis (Scheme 2).

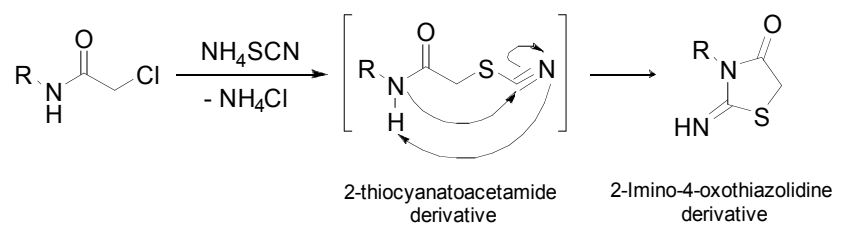

Scheme 1. Postulated mechanism for formation of compound 3.

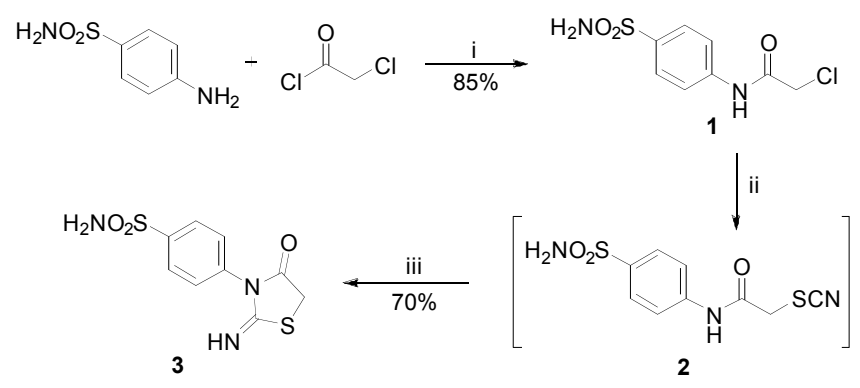

Scheme 2. Synthesis of compound 3. Reagents and conditions: i) $\mathrm{DMF}$, stirr, rt, $1 \mathrm{~h}$; ii) $\mathrm{NH}_{4} \mathrm{SCN}$, acetone, reflux, $2 \mathrm{~h}$; iii) DMF, 120 $130{ }^{\circ} \mathrm{C}, 1 \mathrm{~h}$.

Synthesis of target compounds, 4a-4d was achieved through Knoevenagel condensation of $\mathbf{3}$ with the different aromatic aldehydes. The reaction was carried out in two different solvents; in xylene using catalytic amount of pyridine (method 1) and in glacial acetic acid using sodium acetate as catalyst (method 2). Concerning the yield of the two methods, no significant difference was observed, however the purity of the products using method 2 was found to be better (Scheme 3).

Trial for obtaining Knoevenagel condensation product 4, using acetophenone as a ketone, was found unsuccessful, using both methods at different reflux times (Scheme 4).

The benzylidenethiazolidine-2,4-diones (6a-6d) were prepared by condensing thiazolidine-2,4-dione (5) [31] with different aromatic aldehydes in glacial acetic acid and using catalytic amount of sodium acetate. Alkylation of 6a-6d with 1 in DMF in presence of $\mathrm{K}_{2} \mathrm{CO}_{3}$ at $\mathrm{rt}$ afforded the target thiazolidin-2,4-dione derivatives $\mathbf{7 a - 7 d}$ in satisfied yields (Scheme 5). 


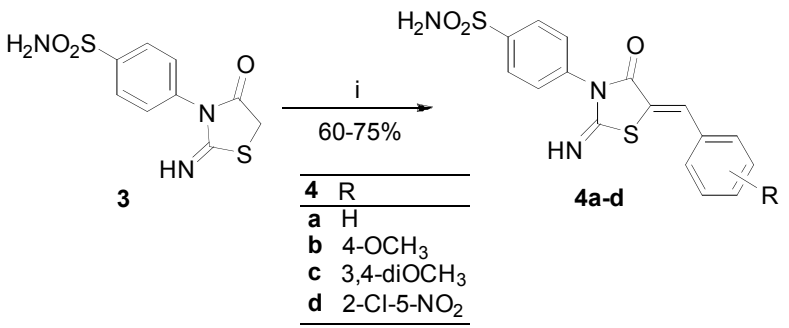

Scheme 3. Synthesis of target compounds 4a-4d. Reagents and conditions: i) method 1: ArCHO, xylene, pyridine, reflux, $6 \mathrm{~h}$; method 2: ArCHO, AcOH, AcONa, reflux, 3 h.

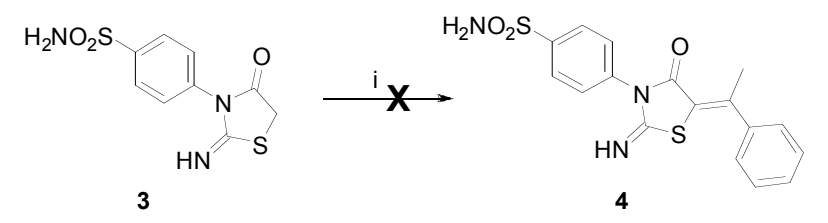

Scheme 4. Unsuccessful trials for synthesis of compound 4. Reagents and conditions: i) method 1: acetophenone, xylene, pyridine, reflux, NR; method 2: acetophenone, $\mathrm{AcOH}, \mathrm{AcONa}, \mathrm{NR}$.

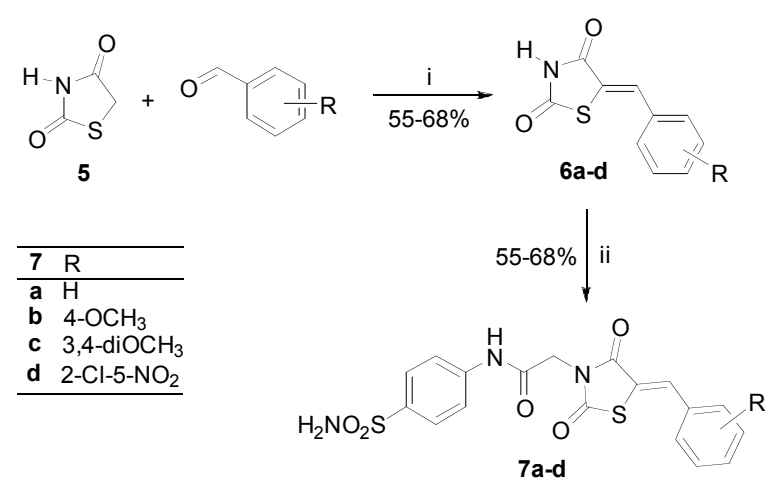

Scheme 5. Synthesis of target compounds 7a-7d. Reagents and conditions: i) $\mathrm{AcOH}$, AcONa, reflux, $12 \mathrm{~h}$; ii) $1, \mathrm{~K}_{2} \mathrm{CO}_{3}$, DMF, rt.

Target compounds $\mathbf{4 a - 4 d}$ and $\mathbf{7 a - 7 d}$ can potentially exist in either $E$ or $Z$ geometrical isomeric forms at the 5-exocyclic double bond. The $Z$ configuration was postulated due to the deshielded methine proton signals by adjacent carbonyl group for both $\mathbf{4 a - 4 d}(\delta$ 7.83-8.18) and $\mathbf{7 a - 7 d}$ $(\delta 7.90-8.02)$ in the ${ }^{1} \mathrm{H}$ NMR spectra. These higher chemical shifts were in coordination with the $Z$ configuration in comparison with the $E$ configuration which expected to have lower chemical shifts [39, 40]. All the newly synthesized compounds were characterized by physical analytical and spectral data and found to be in agreement with predicted values.

\section{Antimicrobial Screening}

The antibacterial activity of the synthesized compounds was determined by using the cup-diffusion technique [35] against Staphylococcus aureus and Bacillus subtilis as examples for Gram-positive bacteria, Escherichia coli and Pseudomonas aeruginosa as examples for Gram-negative bacteria and Candida albicans and Candida tropicalis as example for fungi. The antibacterial assay was carried out using NCCLS (National Committee for Clinical Laboratory Standards) broth dilution method. Compounds that exhibited significant inhibition zones were selected for determination of the minimum inhibitory concentrations (MICs). The minimum inhibitory concentrations (MICs) were determined using 96-well microtitre plates [36, 37].

The results were compared with Ampicillin and Gentamicin for bacteria and Clotrimazole for fungi. The data showed no antifungal activity towards Candida albicans and Candida tropicalis. Whereas, the synthesized compounds exhibited activity against Bacillus subtilis $(\mathbf{7} \mathbf{a}=$ Ampicillin $>$ $\mathbf{4 a}=\mathbf{7 d}$ ) more than Staphylococcus aureus (Ampicillin $>\mathbf{7 d}>$ 7a $>$ 4a) as Gram-positive bacteria and weak antibacterial activity was observed against Gram-negative bacteria.

\section{Anti-Inflammatory Screening}

The anti-inflammatory activity of the synthesized compounds was carried out using carrageenan-induced rat paw edema model [38]. The results revealed that compounds of thiazolidin-2,4-dione series (7a-7d) exhibited greater antiinflammatory activity than the 2-iminothiazolidin-4-one series (4a-4d). The best anti-inflammatory activity was observed with compound $\mathbf{7 b}$. The anti-inflammatory activities of other thiazolidin-2,4-dione derivatives were found in the following order $(\mathbf{7} \mathbf{c}>\mathbf{7 a}>\mathbf{7 d})$. For compounds of iminothiazolidin-4-one series (4a-4d), their anti-inflammatory activities were found to be relatively low and were in the following order $(\mathbf{4} a>4 b>4 c>4 d)$.

\section{CONCLUSION}

As a final conclusion of this research, new derivatives of both 2-Iminothiazolidin-4-one and thiazolidin-2,4-dione derivatives were synthesized via effective and simple chemical pathways. The target compounds were screened for both antimicrobial and anti-inflammatory activity. Screening results revealed that the anti-inflammatory activity was superior to that of antimicrobial activity. Few compounds exhibited good anti-Gram-positive bacteria and week activity on Gram-negative bacteria. The tested compounds showed no antifungal activity. The thiazolidin-2,4-diones (7a-7d) were found to possess more anti-inflammatory potential than the 2-iminothiazolidin-4-ones (4a-4d). The best antiinflammatory activity was observed in compound $\mathbf{7 b}$.

\section{CONFLICT OF INTEREST}

The authors confirm that this article content has no conflict of interest.

\section{ACKNOWLEDGEMENTS}

The authors are very grateful for Dr. Abdelbasset A. Farahat, Department of Pharmaceutical Organic Chemistry, Faculty of Pharmacy, Mansoura University for carrying out the NMR spectroscopy at Georgia State University, Atlanta, Georgia USA.

\section{REFERENCES}

[1] Jain, A. K.; Vaidya, A.; Ravichandran, V.; Kashaw, S. K.; Agrawal, R. K. Recent developments and biological activities of thiazolidinone derivatives: A review. Bioorg. Med. Chem. 2012, 20,3378-3395. 
[2] Abhinit, M.; Ghodke, M.; Pratima, N. A. Exploring potential of 4thiazolidinone: a brief review. Int. J. Pharm. Pharm. Sci. 2009, 1, 47-64.

[3] Raza, S.; Srivastava, S. P.; Srivastava, D. S.; Srivastava, A. K.; Haq, W.; Katti, S. B. Thiazolidin-4-one and thiazinan-4-one derivatives analogous to rosiglitazone as potential antihyperglycemic and antidyslipidemic agents. Eur. J. Med. Chem. 2013, 63, 611-620.

[4] Lee, H. W.; Kim, B. Y.; Ahn, J. B.; Kang, S. W.; Lee, J. H.; Shin, J. S.; Ahn, S. K.; Lee, S. J.; Yoon, S. S. Molecular design, synthesis, and hypoglycemic and hypolipidemic activities of novel pyrimidine derivatives having thiazolidinedione. Eur. J. Med. Chem. 2005, 40, 862-874.

[5] Kunzler, A.; Neuenfeldt, P. D.; das Neves, A. M.; Pereira, C. M. P.; Marques, G. H.; Nascente, P. S.; Fernandes, M. H. V.; Hübner, S. O.; Cunico, W. Synthesis, antifungal and cytotoxic activities of 2aryl-3-((piperidin-1-yl)ethyl)thiazolidinones. Eur. J. Med. Chem. 2013, 64, 74-80.

[6] Bonde, C. G.; Gaikwad, N. J. Synthesis and preliminary evaluation of some pyrazine containing thiazolines and thiazolidinones as antimicrobial agents. Bioorg. Med. Chem. 2004, 12, 2151-2161.

[7] Chawla, P.; Singh, R.; Saraf, S. K. Syntheses and evaluation of 2,5disubstituted 4-thiazolidinone analogues as antimicrobial agents. Med. Chem. Res. 2012, 21, 2064-2071.

[8] Ronad, P. M.; Noolvi, M. N.; Sapkal, S.; Dharbhamulla, S.; Maddi, V. S. Synthesis and antimicrobial activity of 7-(2-substituted phenylthiazolidinyl)-benzopyran-2-one derivatives. Eur. J. Med. Chem. 2010, 45, 85-89.

[9] Sattigeri, V. J.; Son., A.; Singhal, S.; Khan, S.; Pandya, M.; Bhateja, P.; Mathur, T.; Rattan, A., Khanna, J. M.; Mehta, A. Synthesis and antimicrobial activity of novel thiazolidinones. ARKIVOC 2005, ii, 46-59.

[10] Omar, K.; Geronikaki, A.; Zoumpoulakis, P.; Camoutsis, C.; Soković, M.; Ćirić, A.; Glamočlija, J. Novel 4-thiazolidinone derivatives as potential antifungal and antibacterial drugs. Bioorg. Med. Chem. 2010, 18, 426-432.

[11] Mori, M.; Takagi, M.; Noritake, C.; Kagabu, S. 2,4-Dioxo-1,3thiazolidine derivatives as a lead for new fungicides. J. Pestic. Sci. 2008, 33, 357-363.

[12] Vazzana, I.; Terranova, E.; Mattioli, F.; Sparatore, F. Aromatic Schiff bases and 2,3-disubstituted-1,3-thiazolidin-4-one derivatives as antiinflammatory agents. ARKIVOC 2004, v, 364-374.

[13] Prabhakar, C.; Madhusudhan, G.; Sahadev, K.; Maheedhara, R. C.; Sarma, M. R.; Om Reddy, G.; Chakrabarti, R.; Seshagiri, C. R.; Kumar, K. D.; Rajagopalan, R. Synthesis and biological activity of novel thiazolidinediones. Bioorg. Med. Chem. Lett. 1998, 8, 27252730

[14] Amla, A.; Youssef, M.; White, S.; Erika, B.; Ibrahim, M. Synthesis and biological evaluation of novel pyrazolyl-2,4-TZD as antiinflammatory and neuro protective agents. Bioorg. Med. Chem. 2010, 18, 2019-2028

[15] Ceriello, A. Thiazolidinediones as anti-inflammatory and antiatherogenic agents. Diabetes Metab. Res. Rev. 2008, 24, 14-26.

[16] Ialenti, A.; Grassia, G.; Di Meglio, P.; Maffia, P.; Di Rosa, M.; Ianaro, A. Mechanism of the anti-inflammatory effect of thiazolidinediones: relationship with the glucocorticoid pathway. Mol. Pharmacol. 2005, 67, 1620-1628.

[17] Goel, B.; Ram, T.; Tyagi, R.; Bansal, E.; Kumar, A.; Mukherjee, D.; Sinha, J. N. 2-Substituted-3-(4-bromo-2-carboxyphenyl)-5methyl-4-thiazolidinones as potential anti-inflammatory agents. Eur. J. Med. Chem. 1999, 34, 265-269.

[18] Geronikaki, A. A.; Lagunin, A. A.; Hadjipablou-Litina, D. I.; Eleftheriou, E. T.; Filimonov, D. A.; Poroikov, V. V.; Alam, I.; Saxena, A. A. Computer-aided discovery of anti-inflammatory thiazolidinones with dual cyclooxygenase/lipoxygenase inhibition. $J$. Med. Chem. 2008, 51, 1601-1609.

[19] Wu, Y.; Karna, S.; Choi, C. H.; Tong, M.; Tai, H. H.; Na, D. H.; Jang, C. H., Cho, H. Synthesis and biological evaluation of novel thiazolidinedione analogues as 15-hydroxyprostaglandin dehydrogenase inhibitors. J. Med. Chem. 2011, 54, 5260-5264.

[20] Ergenc, N.; Capan, G. Synthesis and anticonvulsant activity of new 4-thiazolidone and 4-thiazoline derivatives. IL Farmaco 1994, 49, $133-135$.
[21] Dwivedi, C.; Gupta, T. K.; Parmar, S. S. Substituted thiazolidones as anticonvulsants. J. Med. Chem. 1972, 15, 553-554.

[22] Hafez, H. N.; El-Gazzar, A. R. Synthesis and antitumor activity of substituted triazolo[4,3-a]pyrimidin-6-sulfonamide with an incorporated thiazolidinone moiety. Bioorg. Med. Chem. Lett. 2009, 19, 4143-4147.

[23] Reddy, K. A; Lohray, B. B; Bhushan, V.; Reddy, A. S.; Kishore, P. H.; Rao, V. V., Saibaba, V.; Bajji, A. C.; Rajesh, B. M.; Reddy, K. V.; Chakrabarti, R.; Rajagopalan, R. Novel euglycemic and hypolipidemic agents: Part-2 antioxidant moiety as structural motif. Bioorg. Med. Chem. Lett. 1998, 8, 999-1002.

[24] Vicini, P.; Zani, F.; Cossini, P.; Doytchinova, I. Hydrazones of 1,2benzisothiazole hydrazides: synthesis, antimicrobial activity and QSAR investigations. Eur. J. Med. Chem. 2002, 37, 553-564.

[25] Ottana', R.; Maccari, R.; Barreca, M. L.; Bruno, G.; Rotondo, A.; Rossi, A.; Chiricosta, G.; Paola, R. D.; Sautebin, L.; Cuzzocread, S.; Vigorita, M. G. 5-Arylidene-2-imino-4-thiazolidinones: Design and synthesis of novel anti-inflammatory agents. Bioorg. Med. Chem. 2005, 13, 4243-4252.

[26] Chavan, A. A.; Pai, N. R. Synthesis and antimicrobial screening of 5-arylidene-2-imino-4-thiazolidinones. ARKIVOK 2007, xvi, 148155.

[27] Sharma, P. K.; Chandak, N.; Kumar, P.; Sharma, C.; Aneja, K. R. Synthesis and biological evaluation of some 4-functionalizedpyrazoles as antimicrobial agents. Eur. J. Med. Chem. 2011, 46, 1425-1432.

[28] Bekhit, A. A.; Fahmy, H. T. Y.; Rostom, S. A. F.; Bekhit, A. E. A. Synthesis and biological evaluation of some thiazolylpyrazole derivatives as dual anti-inflammatory antimicrobial agents. Eur. J. Med. Chem. 2010, 45, 6027-6038.

[29] Apostolidis, I.; Liaras, K.; Geronikaki, A.; Hadjipavlou-Litina, D.; Gavalas, A.; Soković, M.; Glamočlija, J.; Ćirić, A. Synthesis and biological evaluation of some 5-arylidene-2-(1,3-thiazol-2ylimino)-1,3-thiazolidin-4-ones as dual antiinflammatory/antimicrobial agents. Bioorg. Med. Chem. 2013, 21, 532-539.

[30] Alsughayer, A.; Elassar, A. A.; Mustafa, S.; Al Sagheer, F. Synthesis, structure analysis and antibacterial activity of new potent sulfonamide derivatives. J. Biomat. Nanobiotech. 2011, 2, 144-149.

[31] Sohda, T.; Mizuno, K.; Imamiya, E.; Sugiyama, Y.; Fujita, T.; Kawamasu, Y. Studies on Antidiabetic Agents. II. Synthesis of 5[4-(1-Methylcyclohexylmethoxy)-benzyl]thiazolidine-2,4-dione (ADD-3878) and its derivatives. Chem. Pharm. Bull. 1982, 30, 3580-3600.

[32] Ha, Y. M.; Park, Y. J.; Kim, J.; Park, D.; Park, J. Y.; Lee, H. J.; Lee, J. Y.; Moon, H. R.; Chung, H. Y. Design and synthesis of 5(substituted benzylidene)thiazolidine-2,4-dione derivatives as novel tyrosinase inhibitors. Eur. J. Med. Chem. 2012, 49, 245-252.

[33] Jacobs, W. A.; Heidelberger, M. J. On amides, uramino compounds, and ureides containing an aromatic nucleus. J. Am. Chem. Soc. 1917, 39, 2418-2443.

[34] Taniyama, H.; Takemura, S. Studies on thiazole derivatives. I. Synthesis of 4-thiazolidones. Yakugaku Zasshi 1953, 73, 164-165.

[35] Wayne, P. Methods for dilution antimicrobial susceptibility tests for bacteria that grow aerobically, $5^{\text {th }}$ ed., Approved standard M7A5. National Committee for Clinical Laboratory Standards, vol. 20, 2000.

[36] Pelczar, M. J.; Chan, E. C. S.; Krieg, N. R. Microbiology Concepts and Applications, $6^{\text {th }}$ ed.; McGraw-Hill Inc : New York, 1999.

[37] Collee, J. G.; Fraser, A. G.; Marmion, B. P.; Simmons, A. Mackie and McCartney; Practical medical microbiology, $14^{\text {th }}$ ed.; Churchill Livingstone: London, 1996.

[38] Winter, C. A.; Risley, E. A.; Nuss, G. W. Carrageenin-induced edema in hind paw of the rat as an assay for antiiflammatory drugs. Proc. Soc. Exp. Biol. Med. 1962, 111, 544-547.

[39] Bruno, G.; Costantino, L.; Curinga, C.; Maccari, R.; Monforte, F.; Nicolo', F.; Ottana', R.; Vigorita, M. Synthesis and aldose reductase inhibitory activity of 5-arylidene-2,4-thiazolidinediones. Bioorg. Med. Chem. 2002, 10, 1077-1084.

[40] Vicini, P.; Geronikaki, A.; Anastasia, K.; Incertia, M.; Zania, F. Synthesis and antimicrobial activity of novel 2-thiazolylimino-5arylidene-4-thiazolidinones. Bioorg. Med. Chem. 2006, 14, 38593864 .

This is an open access article licensed under the terms of the Creative Commons Attribution Non-Commercial License (http://creativecommons.org/licenses/by-nc/3.0/) which permits unrestricted, non-commercial use, distribution and reproduction in any medium, provided the work is properly cited. 